\title{
Western and Indigenous sciences: colonial heritage, epistemological status, and contribution of a cross-cultural dialogue
}

\author{
Marie-Eve Drouin-Gagné \\ Marie-Eve Drouin-Gagné (mariaevitadg@hotmail.com), Social and Cultural Analysis, Concordia University, \\ Montreal, QC, Canada
}

It often seems difficult making space for Indigenous knowledges in mainstream academia. "Indigenous sciences are not pseudoscience" (Gorelick 2014) addresses the 'demarcation problem' and the rejection of Indigenous knowledges as scientific. Gorelick's (2014) paper problematizes two dimensions of the demarcation between sciences and pseudosciences: (1) the (difficult) definition of science(s), and (2) the often unacknowledged relationship between sciences and myths in both Western and Indigenous traditions. These two dimensions are also important subjects in history, sociology, and anthropology of knowledge.

Gorelick's comment is an important contribution, especially given his own experience in a biology department where Indigenous knowledges are not acknowledged as scientifically valuable to be taught in biology courses. While I am already convinced that Indigenous sciences are not pseudoscience, I want to add two arguments which were missing in Gorelick's paper, and which would make his case for dialogue between Western and Indigenous sciences more convincing.

1) I want to deepen the discussion on the colonial heritage of our system of knowledge and the epistemological status of Western sciences that Gorelick briefly mentioned in his introduction.

2) I want to discuss Indigenous epistemologies and their contribution to sciences, in a dialogue between different scientific knowledges.

As I develop these arguments to promote a crosscultural dialogue in the sciences, I also strive to avoid the pitfalls of postmodern extreme relativism.

\section{Exclusion of Indigenous knowledges: Uncovering the colonial heritage of our knowledge system.}

In the first paragraph of his original paper, Gorelick mentions the colonial relationship between Indigenous and Western societies in the Americas, and its impact on Western consideration for (or dismissal of) Indigenous sciences, politics, arts, etc. He does so by quoting Diamond's perspective (1997) on why Europeans were able to 'conquer' the Americas, namely, that they had developed resistance to certain diseases, and technologies for war. This sociocultural evolutionist perspective rests on environmental and geographical determinism (Blaut 2000), and it accepts the linear 'increasing of complexity' leading to the 'rise of civilizations'. These explanations of the sociocultural reality are built on a biological reflection transferred to history and societies, inspired by the mid- $20^{\text {th }}$ century evolutionist theories in anthropology (such as Childe 1951, Steward 1955, White 1959, or Sahlins and Service 1960) and processual archaeology (Willey and Philips 1958). According to these theories, Europe is a model of the general evolution of societies, "from small bands of huntergatherers in the late Pleistocene and early Holocene, through the first hierarchical societies of the early Neolithic and the states of the Bronze Age and Iron Age" (Price and Feinman 2000: 515).

This approach is not only Eurocentric (Blaut, 2000) in its vision of sociocultural evolution, but it overlooks several facts pointing to the complexity and technological development in the Americas before the $15^{\text {th }}$ century. For example, around $3500 \mathrm{BCE}$, Indigenous societies had developed complex monumental 
architecture and urban complexes in the Andes (e.g. the Sechin complex in Peru). In this same time period, European populations in France and England were in their 'megalithic' chiefdoms phase. Furthermore, according to the description that Richter (2011) makes, similarities can be traced between medieval Europe and medieval North America, each region representing agricultural kingdoms with monumental religious structures. Some archaeologists even point to comparison between Chaco Canyon (in the Four Corners region of modern-day New Mexico) and Irish Kingdoms (Lekson 2009) ${ }^{1}$ or between Cahokia city (along the Mississippi River in modern day Illinois) and European cities such as $15^{\text {th }}$ century Florence (Kehoe 1998: 164) ${ }^{2}$. Finally, Diamond's perspective not only overlooks the cultural interactions and exchanges inside the Americas (e.g. Lekson 2009, Dickason and McNab 2009: 54) and with Pacific and Asian cultures (Dickason and McNab 2009: 32), but his biological account of history also overlooks the political, intellectual, and economic dimensions of colonialism (Tomlinson 1998, McNeill 2001).

Thus, it is essential to present other arguments regarding the colonial relationship between European and Indigenous Peoples in the Americas and their impacts on the Western (lack of) consideration for Indigenous sciences. Given that technological advances and social complexities do not account for European colonization of the Americas, the question remains: How did the European Crowns and their subsequent nation states come to claim ownership over Indigenous Peoples' lands, resources and societies? Indigenous

\footnotetext{
${ }^{1}$ According to Lekson, Chaco Canyon was a civilization, and it was certainly comparable in size and power to the Irish kingdoms of the same period. For example, Chaco Canyon had developed a regional system ruling over 4050000 commoners (Lekson 2009b: paragraph 51, 5657). This system encompassed $103,000 \mathrm{~km}^{2}$, with more than 200 communities and 2000 to $2200 \mathrm{~km}$ of roads around 1100 AD (Sutton 2011; the variation depends of the definition of a "road").

${ }^{2}$ Compared with medieval cities in Europe, Cahokia, with its population of 40,000 at its peak in the $12^{\text {th }}$ century, was a city similar to Venice and Milan, bigger in population than medieval London and Paris and smaller than Constantinople and Seville (Wesler 1995: 6, Kehoe 1998: 153). Based on the social complexity, technologies, and knowledges represented only in the two examples of Chaco and Cahokia, there is no reason to treat North American societies in terms of 'Neolithic time' and 'chiefdoms', while Europe would be 'postIron Age', 'states' and 'civilization' (Wesler 2006). A good popularized summary of up-to-date archaeological and historical knowledges about the Americas before the European colonization is Charles Mann's book 1491 (2005).
}

activists and legal scholars have argued that one of the answers is the Doctrine of Discovery (Williams 2005, Miller 2005, 2008, Newcomb 2008), an old European principle of international law that proclaimed the right of European nations to own the lands they 'discovered' and conquered, at the expense of Indigenous sovereignty (Miller et al. 2012). The basis for this European right to conquer relied on two ideas of a supposed Western superiority: Europeans were superior because they were Christian, and because they were 'civilized' and brought civilization to the Indigenous nations (Miller 2011: 79). Thus, settlers' societies justified the colonial process as a 'civilizing' one, and took it upon themselves to 'educate' Indigenous Peoples according to their ideas of religion and civilization (Lomawaima 1999, Lomawaima and McCathy 2006). Hence, territorial, economic and political colonialism were supported by what Battiste called 'cognitive imperialism' (2005) and 'cognitive assimilation' practices (1986), which dismissed Indigenous Peoples as uncivilized and 'savage' (Williams 2012). Within this intellectual tradition of the Doctrine of Discovery, we can find the main reason for Western dismissal of Indigenous societies, politics, arts, religions, and ultimately sciences. In that vein, Indigenous biologist Kim TallBear (2013) mentions how both Western religion and science are "laden with longstanding narratives of indigenous isolation, unenlightened thought, and deficiency."

These narratives are present in definitions of sciences, even if there is no epistemological consensus within Western sciences when it comes to representing the nature of science, its relationships with reality/facts and beliefs, its development, and method of validation. Yet most epistemological definitions present a hierarchy between knowledge systems, in which science is a 'modern' development established in $17^{\text {th }}$ century Europe, through its emancipation from Christian worldview, absolutism, and obscurantism (Delanty 1997).

For example, based on a positivist approach, Popper (1972) defined science as the most certain kind of knowledge, developed through an evolutionary process of selection of conjectures (tentative theories) and refutation through falsification. Contesting positivism, modernist conceptions of sciences recognize the diverse paradigms in which problems and theories are formulated to explain reality. Nevertheless, science is still conceived as a superior knowledge because it is based on rational abstractions offering logical explanation of phenomena and anomalies (Parsons 1970, Berthelot 1990). When scientific paradigms cannot explain reality, the science can change (Kuhn 1970 [1962]), as opposed to other knowledges that are (erroneously) viewed as static. Similarly, post-modern pragmatic epistemology is still seen as having greater validity than both traditional 'narrative knowledge' and modern 
metaphysical science. Hence, the diverse Western epistemologies seem to share some characteristics, including the principle of evolution ${ }^{3}$ applied to knowledge. In this sense, the Western belief in scientific progress implies dichotomies between tradition and modernity, science and traditional knowledges, as well as a hierarchy of knowledge systems.

Finally, if the evolutionist logic described herein portrays science as an evolved form of knowledge and considers Indigenous Peoples as less 'developed' than Western Peoples, then it is assumed that Indigenous sciences could not have developed similar sophisticated and evolved knowledge as 'Western science'. Hence, we conceive Indigenous knowledge as a local, traditional, mythic pseudoscience. Yet, this conception is much more based on Western history of science and our conception of culture and knowledge evolution, than on the real knowledge developed by Indigenous Peoples. In this sense, we cannot address the demarcation problem outside the sociology and history of scientific knowledge. Likewise, it becomes essential to consider the colonial relationship between Western and Indigenous societies to appreciate the context in which Western modern science has developed its epistemological status regarding non-Western sciences (Agrawal 1995).

\section{Contribution from Indigenous sciences: Discussing Indigenous epistemologies}

Whereas Western science often secures its epistemological status on its 'emancipation' from its original context of enunciation (Bachelard 1934, Berthelot 1990) in its search for objective and universal knowledge, Indigenous epistemologies tend to include an acknowledgement of their context of enunciation in the knowledge validation process. For example, reviewing three different Indigenous perspectives on epistemology (Wilson 2008, Meyer 2001, and Amawtay Wasi 2004), the authors all include history and culture in knowledge

\footnotetext{
${ }^{3}$ As I am by no means an expert in biological evolution, I feel I need to clarify my terminology here. When I talk about evolution principle, the evolutionist theories in social sciences, or their evolutionist logic, I am referring to the general idea, held since the $19^{\text {th }}$ century, that organisms, societies, and cultures not only change through time, but that they increase in complexity. Hence, in spite of the alleged non-teleological nature of both biological and cultural evolution as non-directional changes, the idea of increasing complexity in societies, cultures, and their knowledges in social sciences refers to a certain 'progress' leading to Western model of what a 'modern', 'civilized', 'developed', or 'scientific' society is.
}

definition ${ }^{4}$. Furthermore, each of these authors established dimensions to render this context explicit. Cree scholar Shawn Wilson recognizes diverse paradigms in research, based on four philosophical dimensions (ontology, epistemology, methodology and axiology), adding that "[a]s paradigms deal with beliefs and assumptions about reality, they are based upon theory and are thus intrinsically value laden" (Wilson 2008: 33). Native Hawaiian scholar, Manulani Meyer (2001) identifies seven epistemological dimensions of knowledge that vary from one culture to another. She focuses on the influence of both culture and geography on the sensory relationship that peoples establish with the world, and thus, on the empirical knowledges they develop. Finally, in its elaboration of a curriculum, Ecuadorian Indigenous University Amawtay Wasi recognizes worldviews, myths and axioms as the context in which knowledges are developed that are not invalidated as pseudoscientific. In other words, science is always based on both beliefs (priors) and data, and-given the complexity of reality - all data are never observed or tested at the same time; they are selected and organized according to certain assumptions (Christie 1993, Meyer 2001).

We should question why this recognition of the relationship between scientific knowledge and worldviews or even myths discredits non-Western sciences as anti-scientific (Bala and Gheverghese Joseph 2007). Is Western science's development not also, as Gorelick (2014) mentions, embedded in myths and beliefs just as much as Indigenous sciences? For example, most of Western 'modern' science done in the $20^{\text {th }}$ century relied on principles of material and linear causation, mechanical philosophy, and the search for 'ultimate factors' or unified explanation of the physical world. These ideas relate to the metaphor of a mechanism regulated by natural universal laws, hidden behind the observable reality (Christie 1993). This is in turn consistent with monotheist belief in one God (the 'watchmaker') who pre-established universal laws (Lindberg 2007 [1992]). Similarly, Putz (2012) mentions the influence of Christian linear time, Aristotelian monism adopted in medieval scholastics, and medieval realist notion of deduction of the nature of things according to their acts, on the forging of evolutionist theory in biology. He concludes that "at least historically, then, Catholicism played an instrumental role in the development of [Western] modern biology" (Putz 2012: 307-308). In other words, beliefs,

${ }^{4} \mathrm{I}$ am aware that this is not exclusive of Indigenous epistemologies, and that STS (Science \& Technology Studies) also recognises the influence of history and culture on scientific knowledge, within a Western framework. But I think we would have a more complete perspective including Indigenous epistemologies in the discussion. 
worldviews and myths are not the opposite of scientific knowledge, but rather are what makes its development possible. Hence, according to science historian Lindberg (2007 [1992]), the so-called scientific revolution in Europe of the $16^{\text {th }}$ century was a shift in terms of metaphysics and cosmology, much more than methodology.

Furthermore, Lindberg (2007 [1992]) shows how this shift in Western sciences was possible because of the dialogue with other civilizations, which contributed to Western sciences, especially the Islamic sciences. Bala and Gheverghese Joseph (2007: 47) mention the literature on the "hidden dialogue between western science and other traditions of knowledge" showing a great deal of knowledge transmission from areas east of Europe (such as China and India) back to the west (Europe). But these contributions are not limited to Eurasian exchanges, and they most certainly included Indigenous Peoples of the Americas' scientific contribution. According to Snively and Corsiglia (2001), the amount of knowledge developed by Indigenous Peoples and integrated into 'modern' sciences and technologies should suffice to validate the existence of Indigenous real sciences 5 . Yet, according to Pigluicci and Boudry (2013) to whom Gorelick reacts in his paper, these Indigenous knowledges are 'practical' knowledges or 'empirical' information that can be integrated into the greater framework of universal sciences.

Bala and Gheverghese Joseph (2007: 54) warn against "one-sided attempt to exploit traditional knowledge to advance science, by using traditional techniques and data to further articulate modern scientific theoretical and methodological programmes." They mention that Indigenous knowledges are not only a set of practices and body of information, but also imply theoretical frameworks and methods that ought to be considered if Western sciences are to establish real, equitable, dialogues with other sciences.

\footnotetext{
${ }^{5}$ They mention, amongst other things, the development
of food plants that feed some three-fifths of humanity,

${ }^{5}$ They mention, amongst other things, the development
of food plants that feed some three-fifths of humanity, including thousands of varieties of potatoes, oilseed, squashes, peppers, corn, pumpkins, sunflowers, and beans. Rubber use, vulcanizing, and also platinum metallurgy, as well as mathematics and astronomy with calendars more accurate than those used by Europeans at the time of contact, are also part of the knowledge they highlight. They also mention medicinal knowledge and conclude that "most people do not realize that we are benefiting from the labors of Aboriginal scientists and doctors almost every time we dress, dine, travel, or visit our physicians" (Snively and Corsiglia 2001: 1314).
}

\section{Conclusion: opening dialogue for science, avoiding post-modern relativism}

The scientific revolution in $16^{\text {th }}$ century Europe would not have been possible without the influence of other civilizations' traditions, including Islamic, Chinese and Indian sciences. Therefore imagine what we could learn from real, equitable dialogue with Indigenous sciences and to what other possible 'revolutions' it could initiate. Indigenous knowledges and theories could prove to be complementary and enlightening for Western scientific theories. For example, there are new possibilities that could arise from dialogues between physic and even quantum physics and the Indigenous idea of the relational nature of the world (Duran 2007). In biology, the Lakota 'all my relations' principleacknowledging and honouring the connections that we have as people with plants, animals, marine life, and even microscopic organisms-precedes the current DNA/genome biological understanding of these connections and commonalities among humans and different animals (Bitsóí 2013). In mathematics, faculty at the Amawtay Wasi Indigenous University in Ecuador have pointed to their Andean ancestral mathematics' resemblance to fractal mathematics (Guerrero Ureña 2009). In Alaska, theories of chaos and complexity served as a bridge between Western and Native knowledge systems (Barnhardt and Kawagley 2004 [1998]).

Multicultural recognition of scientific knowledge systems and cross-cultural dialogues between them could prove to be both creative and helpful in the advancement of our understandings of the world. Recognizing that our knowledges are always influenced by beliefs, worldviews, traditions, languages, and cultures is fundamental and will help us be more humble about the limits and validity of our understandings of reality. Furthermore, it will enable 'Western science' to be more respectful of the validity and potential of other knowledges' explanations of the world.

I am certainly not arguing for a post-modern, relativist multicultural perspective on sciences, which could "obliterate the distinction between knowledge and fiction" (Bala and Gheverghese Joseph 2007). Rather, I am arguing for the potential in having a dialogical approach of complementarity between different sciences. By applying complexity to sciences, with the assumption that reality is complex and that no knowledge system can account for the whole reality (Eve et al. 1997), it is possible to consider multiple knowledge systems and their contribution to the sciences (ManuelNavarrete 2008). Nevertheless, a complex dialogue between Western and Indigenous academia and their knowledge systems will require a holistic perspective on the relation between the knowledge produced and history, politics, and social change. 


\section{References}

Agrawal, A. 1995. Dismantling the divide between Indigenous and Western knowledge. Development and Change 26: 413-439. CrossRef

Bachelard, G. 1977 [1934]. La formation de l'esprit scientifique. Contribution à une psychanalyse de la connaissance objective. Vrin, Paris.

Baker, D. 1996. Does 'indigenous science' really exist? Australian Science Teachers' Journal 42: 18-20.

Bala, A., and G. Gheverghese Joseph. 2007. Indigenous knowledge and western science: the possibility of dialogue. Race Class 49: 39-61. CrossRef

Barnhardt, R., and A. Oscar Kawagley. 2004 [1998]. Culture, chaos and complexity: Catalysts for change in Indigenous education,Cultural Survival Quarterly 27: 59-64.

Battiste, M. 2005. Indigenous knowledge: Foundations for First Nation. World Indigenous Nations Higher Education Consortium (WINHEC) Journal, retrieved August 302013 from: http://www.truworld.ca/ _shared/assets/Batiste-Indigenous-Knowledge293 32.pdf

Battiste, M. 1986. Micmac literacy and cognitive assimilation. Pages 23-45 in Barman, J., Hébert, Y., and D. McCaskill, editors. Indian Education in Canada, Volume 1: The Legacy. UBC Press, Vancouver.

Berthelot, J-M. 1990. L'intelligence du social : le pluralisme explicatif en sociologie. Presses universitaires de France, Paris.

Bitsoi, L. 2013. Enhancing genomic research through a Native lens. Lecture given on May 31 2013, at the Salish-Kootenai College Campus, Pablo, Montana.

Blaut, J.M. 1993. The Colonizer's Model of the World. Geographical Diffusionism and Eurocentric History. The Guilford Press, New York, London.

Childe, G.V. 1951. Social evolution. Watts, London.

Christie, M. 1993. Aboriginal science for the ecologically sustainable future. Chain Reaction 68, retrieved January 282014 from: http://www.uow.edu.au/ $\sim$ sharonb/STS300/science/nature/articles/artindigeno $\underline{\text { us 1.html }}$

Delanty, G. 1997. Positivism, science, and the politics of knowledge. Pages 11-38 in Social science: beyond constructivism and realism. University of Minnesota Press, Minneapolis.

D'Errico, P. 1999. Native Americans in America: A theoretical and historical overview. Wicazo Sa Review 14: 7-28. CrossRef

Diamond, J. 1997. Guns, germs, and steel: the fates of human societies. W. W. Norton, New York.

Dickason, O.P., and D.T. McNab. 2009. Canada's First Nations. A History of Founding Peoples from Earliest Times. Oxford University Press, Don Mills.
Duran, P.H. 2007. On the cosmic order of modern physics and the conceptual world of the American Indian. World Futures: The Journal of New Paradigm Research 63: 1-27.

Eve, R.A., Horsfall, S. and M.E. Lee, editors. 1997. Chaos, Complexity and Sociology. Myths models and theories. Sage Publications, New York and New Delhi.

Gonella-Frichner, T. 2010. The "Preliminary Study" on the Doctrine of Discovery. Peace Environmental Law Review 28: 339-345.

Gorelick, R. 2014. Indigenous sciences are not pseudoscience. Ideas in Ecology and Evolution 7: 43-55. CrossRef

Guerrero Ureña, M. 2009. Fundamento científico de la interculturalidad. Seminario Internacional el Movimiento Indígena y la Educación Superior en Abya Yala, Memorias, Kitu (Quito): 81-95.

Kehoe, A.B. 1998. The Land of Prehistory: A Critical History of American Archaeology. Taylor \& Francis, Oxford and New York.

Kuhn, T.S. 1970. The Structure of Scientific Revolutions. Chicago University Press, Chicago.

Lekson, S.H. 2009. A History of the Ancient Southwest. SAR Press, Santa Fe.

Lindberg, D. 2007 [1992]. The Beginnings of Western Science: The European Scientific Tradition in Philosophical, Religious, and Institutional Context, Prehistory to A.D. 1450. University of Chicago Press, Chicago.

Lomawaima, T. 1999. The unnatural history of American Indian education. Pages 1-32 in Tippeconnic, J.W. and K. Gayton Swisher, editors, Next Steps. Research and Practice to Advance Indian Education. Eric, Charleston.

Lomawaima, T. and T.L. McCarty. 2006. To remain Indian: Lessons in Democracy from a century of Native American education. Teachers College Press, New York.

Lyotard, J-F. 1984 [1979]. The Post-Modern Condition: a Report on Knowledge. University of Minnesota Press, Minneapolis.

Mann, C.C. 2005. 1491: new revelations of the Americas before Columbus. Knopf, New York.

Manuel-Navarrete, D. 2008. Approaches and Implications of using Complexity Theory for dealing with Social Systems. CiteSeer, The College of Information Sciences and Technology, Pennsylvania State University. Retrieved on January 282014 from: http://citeseerx.ist.psu.edu/viewdoc/summary?doi=10 .1 .1 .105 .8069

McNeill, J.R. 2001. The World According to Jared Diamond. The History Teacher 34. 165-174. CrossRef 
Meyer, M.A. 2001. Our own liberation: Reflections on Hawaiian epistemology. Contemporary Pacific 13: 124-48. CrossRef

Miller, R.J., Ruru, J., Behrendt, L., and T. Lindberg. 2012. Discovering Indigenous Lands: The Doctrine of Discovery in the English Colonies. Oxford University Press, Oxford.

Miller, R.J. 2008. Native America, Discovered and Conquered: Thomas Jefferson, Lewis and Clark, and Manifest Destiny. University of Nebraska Press, Lincoln and London.

Miller, R.J. 2005. The Doctrine of Discovery in American Indian Law. Idaho Law Review 42. Retrieved on January 20 2013, from: http://papers.ssrn.com/sol3/ papers.cfm?abstract $\mathrm{id}=721631$.

Miller, R.J. 2011. The International Law of Colonialism: a comparative analysis. Lewis \& Clark Law Review 15: 847-922.

Morgan, L.H. 1964 [1877]. Ancient Society or Researches in the Lines of Human Progress from Savagery through Barbarism to Civilization. MacMillan \& Company, London.

Newcomb, S.T. 2008. Pagans in the Promised Land Decoding the Doctrine of Christian Discovery. Fulcrum Publishing, Golden.

Parsons, T.T. 1970. An approach to the sociology of knowledge. Pages 282-306 in J.E. Curtis and J.W. Petras, The Sociology of Knowledge. Gerald Duckworth, London.

Pigliucci, M. and M. Boudry. 2013. The dangers of pseudoscience. New York Times, 10 October 2013. http://opinionator.blogs.nytimes.com/2013/10/10/thedangers-of-pseudoscience/? $\mathrm{r}=0$

Popper, K.R. 1972. Objective Knowledge: An Evolutionary Approach. Clarendon Press, Oxford.

Putz, O. 2012. Evolutionary biology in a Catholic framework. Pages 307-330 in J. J. Piderit and M. M. Morey, editors. Teaching the Tradition. Catholic Themes in Academic Disciplines. Oxford University Press, New York. CrossRef

Price, D.T. and G.M. Feinman. 2000. Images of the Past. Mayfield Publishing Company, Mountainview, London, Toronto.

Sahlins, M.D. and E.R. Service, editors. 1960. Evolution and culture. University of Michigan Press, Ann Arbor.

Snively, G. and J. Corsiglia. 2001. Discovering Indigenous science: implications for science education. Science Education 85: 6-34. CrossRef

Steward, J.H. 1955. Theory of culture change: the methodology of multilinear evolution. University of Illinois Press, Urbana.

TallBear, K. 2013. Tell me a story: Genomics vs. Indigenous origin narratives. Genewatch 26 Retrieved 29 January 2014 from: http://www.councilfor
responsiblegenetics.org/GeneWatch/GeneWatchPage. aspx?pageId $=495$.

Tomlinson, T. 1998. Review of Guns, Germs and Steel: The Fates of Human Societies. Reviews in History (review no. 51). Institute of Historical Research, University of London. Retrieved 30 January 2014 from http://www.history.ac.uk/reviews/review/51.

Amawtay W., Universidad Intercultural Indígena, and UNESCO. 2004. Learning Wisdom and the Good Way to Live. Universidad Intercultural Amawtay Wasi/UNESCO, Quito.

White, L. 1959. The Evolution of culture. McGraw-Hill Co., New York.

Williams, R.A. 2012. Savage Anxieties. The Invention of Western Civilization. Palgrave MacMillan, New York.

Williams, R.A. 2005. Like a Loaded Weapon. The Rehnquist Court, Indian Rights, and the Legal History of Racism in America. University of Minnesota Press, Minneapolis.

Wilson, S. 2008. Research is Ceremony: Indigenous Research Methods. Fernwood Publishing, Black Point and Winnipeg.

Willey, G.R., and P. Phillips. 1958. Method and Theory in American Archaeology. University of Chicago Press, Chicago. 